\title{
Floor of Mouth Basaloid Squamous Cell
} Carcinoma

National Cancer Institute

\section{Source}

National Cancer Institute. Floor of Mouth Basaloid Squamous Cell Carcinoma. NCI

Thesaurus. Code C129873.

An aggressive variant of squamous cell carcinoma that arises from the floor of the mouth. It is characterized by the presence of small malignant cells with hyperchromatic nuclei and scant amount of cytoplasm forming lobules with peripheral palisading. 